\title{
Grape Winery Waste as Feedstock for Bioconversions: Applying the Biorefinery Concept
}

\author{
Myrto-Panagiota Zacharof $^{1}$ (D)
}

Received: 20 May 2016/Accepted: 22 August 2016/Published online: 27 August 2016

(c) The Author(s) 2016. This article is published with open access at Springerlink.com

\begin{abstract}
Grape wine is among the most important alcoholic beverages in the globe, with a continuously rising world demand, currently sizing at 25 billion litres. Such a large and heavily industrialised market calls for the maintenance of a steady production of raw materials to end products. Consequently, intensive cultivation of land, harvesting of the goods and manufacturing for the production of commercially available products are being implemented. Wine making is a timed, multistage process producing a large amount of organic and inorganic waste. It has been calculated that during cultivation and harvesting about 5 tonnes of solid waste are generated per hectare per year, while the winery wastewater varies according to the production size from $650,000 \mathrm{~m}^{3}$ (Greece) to over $18,000,000 \mathrm{~m}^{3}$ (Spain) per year. Conventional treatments of winery waste are becoming increasingly expensive, demanding significant amounts of effort, resources and energy for safe waste discharge. Therefore, the need to recycle, reuse and recover energy and valuable chemicals from winery waste and wastewater becomes apparent. Valorisation of winery waste is possible when introducing the concept of biorefinery, i.e. the use of winery waste as bioconversions feedstock in order to produce platform chemicals, biofuels, heat and energy.
\end{abstract}

Keywords Biorefinery - Winery waste $\cdot$ Feedstock · Bioconversion - Biofuels · Platform chemicals - Waste valorisation

Myrto-Panagiota Zacharof myrtozacharof1981@yahoo.com;

M.Zacharof@swansea.ac.uk

1 Centre for Cytochrome P450 Biodiversity, Institute of Life Science, Swansea University Medical School, Swansea, Wales SA2 8PP, UK

\section{Introduction}

Grape wine represents one of the most important alcoholic beverages in the world, with a continuously growing demand. While traditionally wine production and consumption was concentrated in the European continent, currently over 67 nations produce, export, import and consume wine including Australia, New Zealand, Latin America (Chile, Argentina) and South Africa, all competing for a share of above 25 billion litres world market [1].

The industry continuous to be dominated by the "Big Three": Italy, France and Spain; however the US and Australia are becoming producers of significant size [2]. France is the first wine producing country in the world with 41.4 million of hectolitres or $16.4 \%$ of the global production each year, followed by Italy with 40.1 million of hectolitres or $15.9 \%$ and Spain with 30.4 million of hectolitres or $12.1 \%$ [3, 4]. China, on the other hand, is the largest producer of grapes contributing $13 \%$ of the world's production, but limited information is available on wine production in the country and the majority of grapes are exported elsewhere [2].

Such a large and heavily industrialised market calls for the maintenance of a steady production of products. Therefore, intensive cultivation of land, harvesting of the goods and manufacturing is needed and is implemented. Wine making is a timed, multistage process producing a large amount of organic and inorganic waste. During cultivation and harvesting, waste has been calculated at about 5 tonnes per hectare of land per year $[5,6]$ while the winery wastewater varies according to the production size from $650,000 \mathrm{~m}^{3}$ (Greece) to over $18,000,000 \mathrm{~m}^{3}$ (Spain) per year [7].

The winemaking industry has been majorly positively portrayed, due to the socioeconomic and cultural benefits 
attributed to it $[8,9]$. Regardless of the vast amounts of waste generated, the great use of water resources and the exhaustive land usage, the industry has not been viewed negatively by the general public. This, in turn, has encouraged its development and consequent generation of higher amounts of waste.

Waste can be seen as a virtually inexhaustible resource, being utilized in industrial markets to generate combined heat and power (CHP) and fertilizers, in the affluent developed world [10, 11]. Within the coming decade, these markets will develop further, as well as shifting into recovering chemicals and generating energy, synthetic materials, feeds and food from the waste, in an effort to reduce the carbon footprint of their production, as a result of legislative, environmental, economic and social drivers [12]. Utilizing natural resources will place limitations on manufacturing, but will also achieve environmental sustainability and will constitute non-solid waste safe for environmental discharge, in the form off particle, nutrient free and sterile effluents [13]. Therefore the utilization of waste as a valuable commodity and platform chemicals "mine" is an important step for the development and deployment of alternative sources of energy production [14].

Conventional treatment of waste is becoming increasingly expensive, demanding significant amounts of effort, resources and energy for safe waste discharge into the environment [15]. Tightening legislations regarding waste disposal call for alternative solutions to methods such as landfilling, landspreading or disposal in water streams such as rivers. In the current knowledge-driven economy that aims for low carbon use, and with the growing awareness of environmental protection-due to climate change and natural resources exhaustion-, the need to recycle, reuse and recover energy and valuable chemicals from waste and wastewater becomes apparent [16].

Therefore, the overall aim of this review is to explore schemes that could be applied at an industrial scale to valorise winery waste, introducing the concept of biorefinery, i.e. the use of winery waste as source of platform chemicals, fuels, heat and energy.

\section{Energy and Commodities Formation from Alternate Origins: The Biorefinery Idea}

Using agricultural goods for the production of other products is barely a novelty. However, the use of plant biomass as a raw material for the production of numerous products using complex physicochemical processing methods, a concept similar to petroleum refinery, is a rather new idea, first initiated in the $1980 \mathrm{~s}[8,17]$. This approach though successful to an extent has several drawbacks. Plant based biomass is a rich source of lignin, carbohydrates, proteins and fats, also containing in smaller amounts vitamins, dyes and flavours $[18,19]$. Its utilisation as bioconversion substrate requires extensive, often costly, pre-treatment in order to be processed successfully by the microorganisms. It has to be intensively cultivated and grown to produce considerable amounts of fuels, chemicals and power. This leads to land competition for crops development, potential shortage of feedstock, environmental constraints, due to excessive use of fertilisers, human food and export market, as well as possible water shortage [20].

Therefore, in recent years there is a shift from the whole crop concept - where an entire crop of wheat, rye, barley, corn or triticale is used as feedstock - to the waste based concept mainly in lignocellulose feedstock, where hard fibrous plant materials generated from agricultural or forestry activities are used [21]. This approach, albeit beneficial, has been hard to apply due to the extensive demand in pre-treatment (enzymatic hydrolysis or chemical digestion) for the production of cellulosic and hemicellulose material [22].

Moreover, several researchers [23, 24] have highlighted the importance of recycling waste, municipal, agricultural, domestic, and industrial, through bioconversion, i.e. applying a biorefinery (Fig. 1) concept, but with waste as the main feedstock.

This approach has been voiced by numerous governmental and non-governmental bodies and most importantly by the European Union [25-29] which has called for the increase of the recycling and preparing for re-use of municipal waste to $70 \%$ by 2030 , and has stipulated phasing out landfilling recyclable waste (including plastics, paper, metals, glass and bio-waste) in non-hazardous waste landfills, reducing landfilling to a maximum of $25 \%$ by 2025 .

Waste, depending on its origin, contains various highvalue chemical substances and elements, including carbon sources in the form of carboxylic and other acids, carbohydrates, proteins, nitrogen $(\mathrm{N})$ as ammonia, phosphorus (P) and metals. The use of recovered materials from waste would be highly beneficial for the environment and the economy. For example; phosphate rock is a non-renewable natural resource, of critical importance because of its numerous applications including drinking water softening, feed and food additives, and fertilisers. Although its production is carbon neutral, mining $\mathrm{P}$ is gradually becoming more costly and supply risks, related to environmental and socio-political issues, have risen. It has been reported that by 2035 the demand for $\mathrm{P}$ will outpace the supply as the finite resource becomes increasingly expensive (800\% rise between 2006 (\$50) and 2008 (\$400), current value of over $\$ 500 /$ tonne) On the other hand, $\mathrm{P}$ removal from wastewater has to improve as water discharge standards become more stringent, raising the costs of wastewater treatment [30]. Substantial value also exists in the high content of metal ions in numerous agricultural and industrial wastes. 
Fig. 1 The petroleum refinery versus the biorefinery concept $[16,67,69,73,117]$

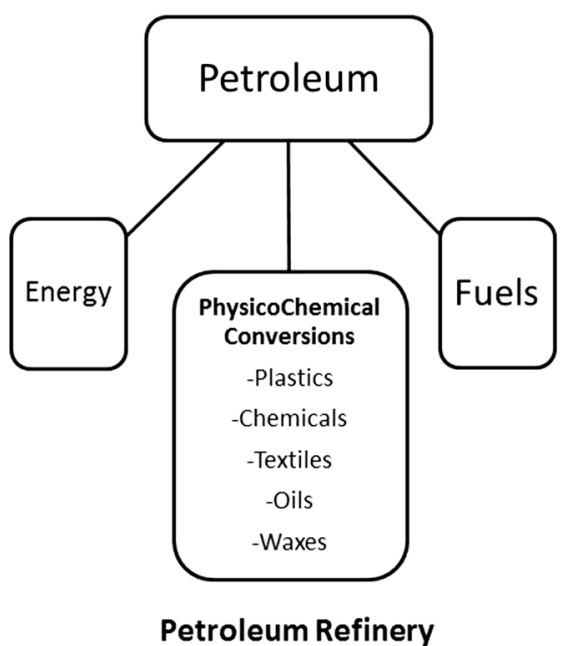

Ammonia, another resource, has a market value of $\$ 800 /$ tonne and its global consumption exceeds 150 million tonnes. As well as being used heavily in fertilisers, it is also an important component of various commercial and industrial products. These include fuels, antimicrobial agents, woodworking agents and cleaners. It has a large production carbon footprint (best practice being 2.2 tonnes of $\mathrm{CO}_{2}$ per tonne of ammonia), as during its synthesis methane is reformed to produce $\mathrm{H}_{2}$ and $\mathrm{CO}_{2}$. In addition, the disposal and return of ammonia to the atmosphere through nitrification and denitrification adds additional costs to wastewater treatment [30].

Therefore, reclaiming these valuable chemicals into formulated feedstock suitable for biochemical conversion to industrially relevant products, is a crucial step in improving sustainability and reducing environmental impact. Multiple benefits lie in this approach including: recycled materials will substitute newly synthesized or mined materials; the reduction in the volume and concentration of waste will reduce demand and costs in waste treatment plants and methane emissions in the landfills; recovery of ferrous and non-ferrous metals from the waste streams for recycling is more energy efficient than mining for virgin resources; electricity generated by methane generation through anaerobic digestion offsets electricity generated from fossil fuels; valuable streams, such as formulated of nutrient streams, are created for application in agriculture and bioprocessing [31, 32].

\section{Waste: A Sustainable Point of Supply of Resources and Energy}

In the context of a current high energy demand economy, with growing awareness of environmental protection and the strengthening of water resource and wastewater related legislation; the need to recover and produce energy and chemicals from wastes becomes apparent [33]. The continuously rising human population results in rising demand for food, energy and water. This growing global urbanization coupled with elevated environmental awareness, expressed by various steep legislative frameworks over waste disposal as well as public pressure, are pushing private and public waste treatment providers to review and reengineer their waste management strategies [29, 34].

The development of novel, cost-effective waste management methodologies is of great interest to various groups such as contractors, engineering consultants, equipment providers, policy regulators (agencies, politicians, and think tanks), and the general public and depends on the needs of the community in a microscale but also on the general good in a macroscale (Fig. 2) [23, 35, 36]. Waste can be divided in numerous categories (Fig. 3) according to type, governing legislation origin or state of matter [37].

Probably not all waste types are suitable to use as biorefinery feedstock, since several complications due to their complex physicochemical nature might occur. Implications relevant to transportation or the need of extensive costly pre-treatment might hinder the use, for instance, of construction waste. Construction waste may include lignocellulosic material but due to its heavily mixed nature and current ways of collection is unsuitable for such an approach [37].

Waste generated by the beverage, food, feed, and agricultural industry is certainly the best candidate for the biorefinery approach, satisfying criteria such as size, continuity of supply and nutritive content. Beverage and food production has become heavily industrialised and therefore regulated generating tons of waste per annum $[38,39]$. The food industry is shifting towards the intensive production of ready to eat foods (RTE) that are consumed in venues 


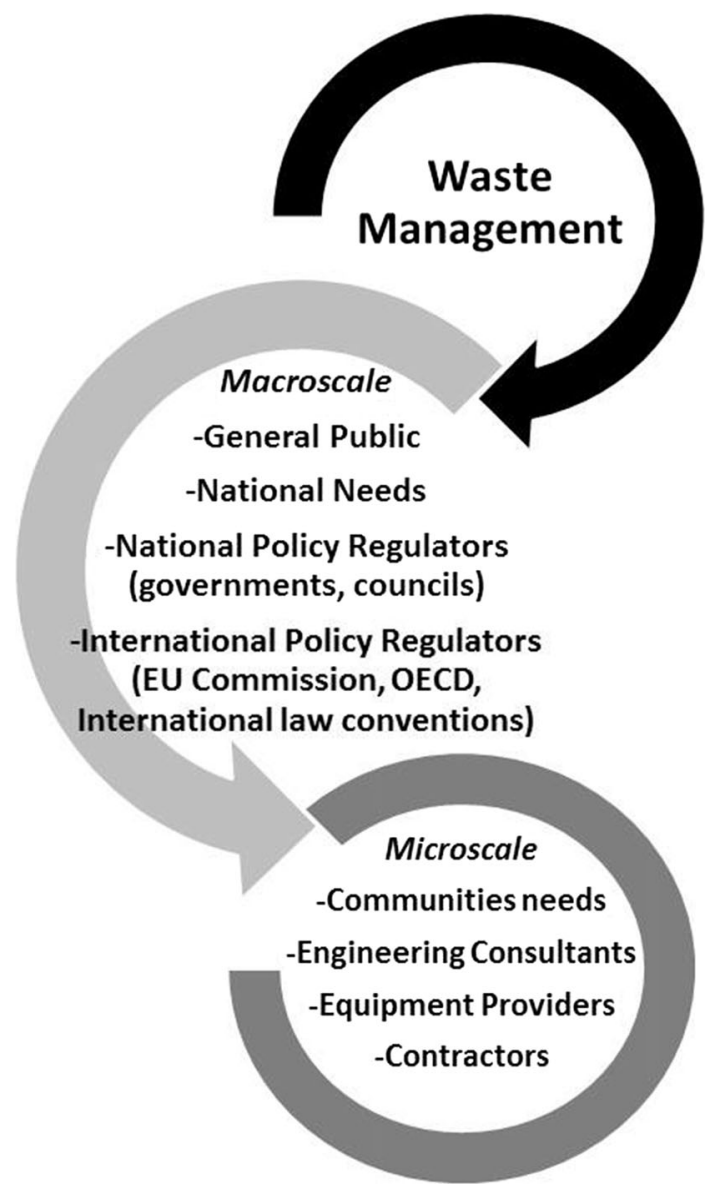

Fig. 2 Decision making process regarding waste management [52]

that have fewer conventional methods of stabilizing food, therefore resulting in even larger amounts of waste [40]. In addition to the directly occurring waste due to food processing (slaughterhouse, dairy, wheat and corn milling, confectionary, sugar and starch processing, vegetative processing, fish and poultry processing, alcoholic and nonalcoholic beverages and soft drinks manufacturing and processing), the food industry is linked to agricultural waste (organic waste and agricultural residues) produced by intensive animal and crop farming to satisfy food demand, reaching a 264,854 tonnes per annum [41] in United Kingdom alone. Agricultural waste is third in terms of waste industry size, comparable only to municipal solid waste [42, 43] and it imposes environmental threats, since conventional treatments-such as landfilling or landspreading - may cause eutrophication and land and water toxicity, due to freely available nutrients and metals spread in water and soil. There are also human health concerns due to land related pathogenicity contained in the raw materials [44].

Industrial wastewaters from food processing industries, wineries, breweries and agricultural wastewater from animal confinements are ideal candidates for biotechnological production of high value substances and platform chemicals $[45,46]$ however their effective formulation remains a desideratum. These effluents, if used as nutrient media, are potentially highly profitable, especially when compared to the traditional synthetic media or that derived from food sources such as crops. For example, the cost per kilo of Man de Rogosa broth, a well-known nutrient medium used in research and development of starter cultures used in dairy industry can reach $\$ 1311$ per kilo, while a formulated waste deriving nutritive effluent can cost as little as $\$ 2.4$ per kilo of nutrients (acids, ammonia, phosphate) recovered [47].

Previous research [48-50] has shown the strong potential of discharged waste effluents to be used as feedstock
Fig. 3 Waste categories and types $[25,27,29,35,36,118]$

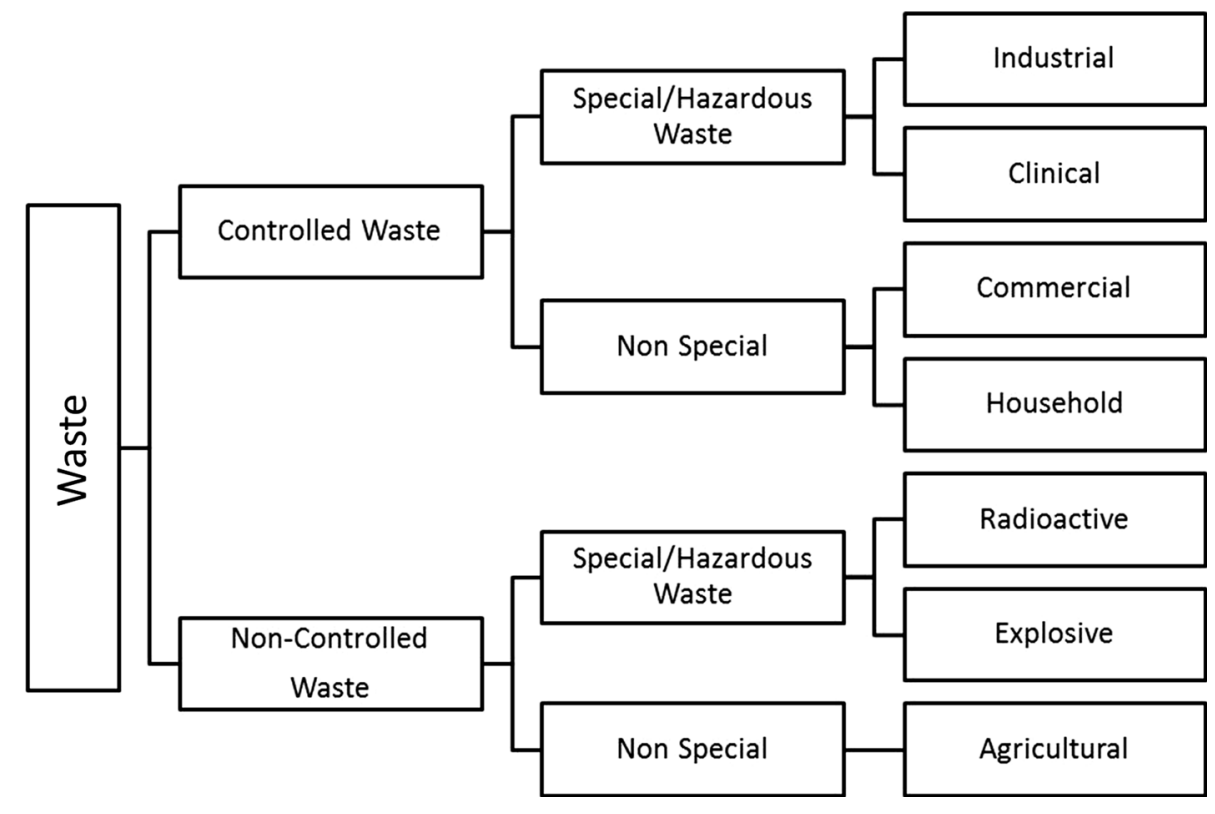


for the production of various biobased chemicals (Fig. 4). Consequently, waste can represent an ideal feedstock, since the main focus of a biorefinery is to produce low-value, high-volume (LVHV) products to meet the global energy demand simultaneously with the production of high-value, low-volume (HVLV) products that enhance profitability, while the production of CHP can be used to reduce the costs of processing procedures.

Among the several kinds of food industry related waste, wine industry waste is of major interest for such an approach.

\section{The Winery Waste as Biorefinery Substrate}

\section{Grape Wine Production Process}

Wine is produced by the botanical genus Vitis (grapes), while most of the European wines are produced from the species Vitis vinifera.

Wine production is an important part of agriculture and beverage industry worldwide. According to the latest evidence, in 2012 only, 253,000,000 hectolitres of wine where produced worldwide [51]. An average winery is capable of crushing 100 tons of grapes per season, since wine making is a seasonal task occurring in the south hemisphere from January to April and in the north hemisphere between August and October. Grape wine has three main genres, still, sparkling and fortified, with still wine production gaining the major part of the market. Still wine is produced via fermentation through three different routes (skins, peeled and smashed grapes) resulting in different types, white, rose and red. In brief, wine making follows a multiple step process including destemming, crushing, and fermentation, pumping over and pressing (Fig. 5).

The grapes are normally delivered to the winery during autumn (August-October). Destemming, the process of partial or total removal of stems from the grapes, is applied for white or rose wines. Then the grapes are separated depending on whether they can or cannot be crashed, so pulp and juice are released. Crushing is done mechanically, since former manual process may split the skin or simply crack it. The grapes come through a pneumatic press and produce must and solid residues. The produced amount of must is about $80 \mathrm{~L}$ per $100 \mathrm{~kg}$ of grapes [52-54]. The fermentation stage for red wine is done on solid parts; the fermenting must is in contact with the seeds, skins, and sometimes even stems, while for white wine the solid parts are not that much involved and the decanting stages might be different. The conversion of grapes sugar into alcohol and carbon dioxide by yeasts takes place in a stainless steel, cement or wooden fermentation tanks after pressing, since the solids part should be in contact with the must to impart colour, odour and texture. During fermentation, continuous mixing is required, as grapes' solid parts have the tendency to surface. Continuous mixing ensures the homogenous distribution of physicochemical conditions and yeasts.

After fermentation, decanting takes place. During this process, the supernatant wine is separated from the produced wine lees and is fed by pumps to empty tanks that are filled completely for further stabilization. The wine lees are at a concentration of $5 \% \mathrm{v} / \mathrm{v}$, and are used for to alcohol production [55]. The next stage is maturation,
Fig. 4 Use of non-waste and waste streams within the biorefinery concept $[48,73]$

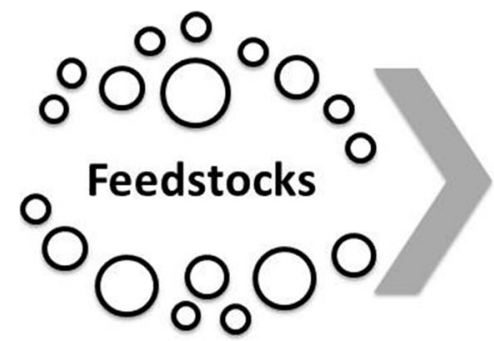

- Agricultural crops

- Agricultural residues \&waste

- Food waste (industrial, domestic)

- Beverage waste (crops, processing)

- Forestry waste

- Municipal solid waste

\section{Biorefinery Conversion Processes \\ - Biological/ Biochemical \\ - Enzymatic/Acid \\ - Chemical \\ - Gasification \\ - Pyrolysis \\ - Separation \\ - Extraction}
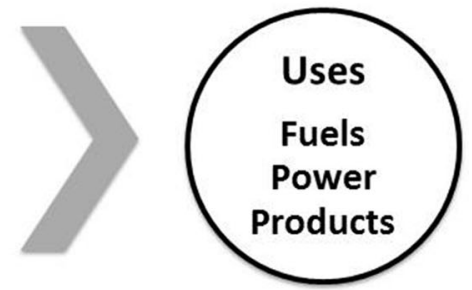

- Bioethanol

- Biobutanol

- Biodiesel

- Gases (Biogas/Hydrogen)

- Electricity

- Heat

- Bioplastics (Polyhydoxyalkanoates)

- Chemicals

- Detergents

- Chemical intermediates

- Enzymes 


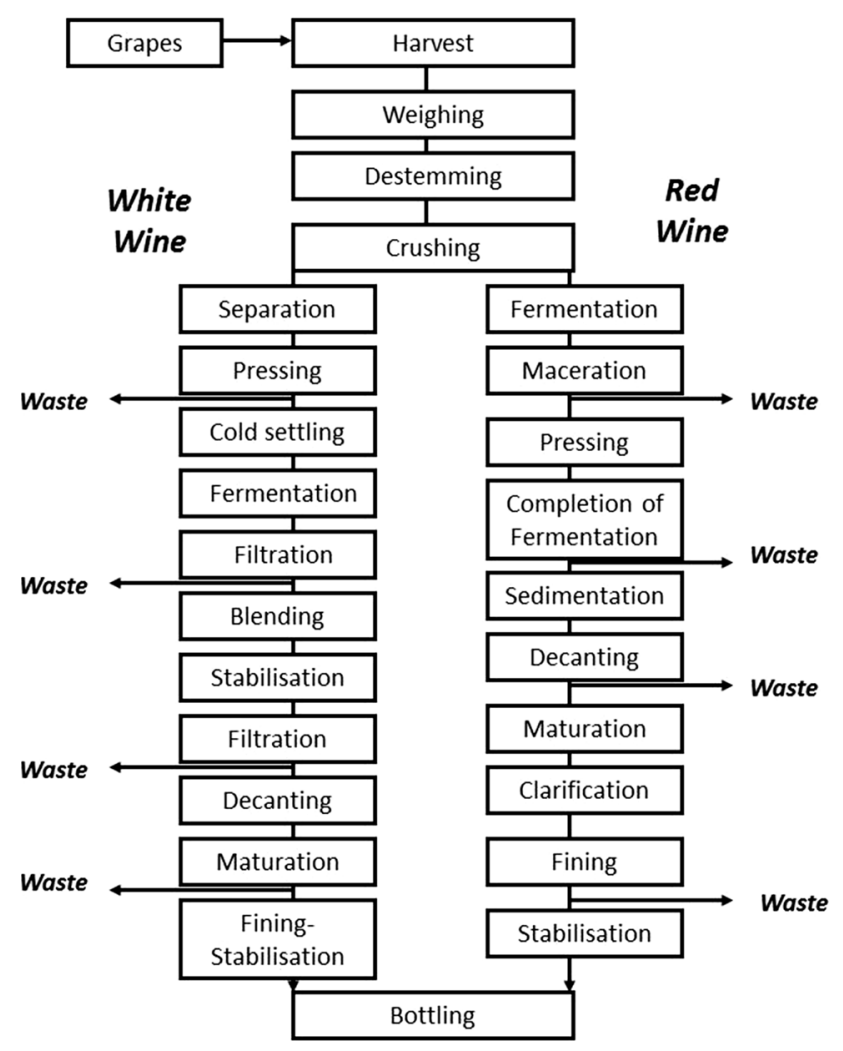

Fig. 5 Waste generation during the wine making process $[5,6,59,63]$

where decanted wine is kept in maximum capacity filled vessels. After maturation and stabilisation, wine is clarified using chemical agents (fining) (Fig. 5) for quality improvement and then is decanted into empty tanks. After the desired timed period for settling has elapsed, wine is bottled on transportation tanks and distributed to the contact points.

\section{Origins of Grape Winery Waste}

Winery waste can be divided into two main categories, solid and liquid waste. Solid waste is generated during the collection of grapes and liquid waste is generated during the wine making process (Fig. 5) Solid winery waste, namely grape stalks, grape pomace and grape seeds, varies in chemical composition and texture. In terms of percentage it is composed of up to $7.5 \%$ grape stalks, up to $45 \%$ grape pomace, up to $6 \%$ grape seeds and various other waste sources [56]. Grape stalks are the major by-product of vineyards with an average production of 5 tonnes per hectare per year [57]. They are rich is lignin, cellulose, $\mathrm{N}$ and potassium $(\mathrm{K})$, having a high agronomic value and are used for composting [58]. Grape stalks have been found to be highly effective for soils, as they have low organic matter content [59].
Grape pomace contains up to $15 \%$ sugars, $0.9 \%$ pigments and phenolics, especially in the case of red grape pomace, up to $1 \%$ tartrate acid and up to $40 \%$ fibre. Grape pomace is being used as a feed additive due to its high fibre content. Grape seeds are very rich in linoleic acid and omega6 fatty acids, with up to 17 and up to $6 \%$ phenolics [60].

Winery waste, however, is not limited to waste generated at the first stages of grape harvesting and initial stages of wine formulation. Waste known as lees, composed of solid and liquid fractions, is generated during the fermentation and maturation stages [61, 62]. The solid part is comprised of the remains precipitated at the bottom of the tanks, mainly consisting of bacterial biomass, undissolved carbohydrates of hemi- or cellulosic nature, phenolic compounds, lignin, proteins, metals, inorganic salts, organic acid salts (mainly tartrates, in the case of wine lees) and other materials such as pips (tannins sustaining grape seeds), fruit skins, grains and seeds. The liquid phase is represented mainly by the spent fermentation broth, often rich in organic acids and ethanol. Vinasses, a by-product of the wine lees, are defined as liquid fraction waste deriving from the distillation process of the wine lees, which is carried out to recover ethanol and elaborate distilled beverages $[13,62]$.

A vast amount of waste, in the form of wastewater is generated during the further stages of processing, including fermentation (vessels pre- and postwashing), storage and maturation (pre- and post-washing of storage tanks, preand postwashing of fermentation vessels, spillages), clarification (wastewater generated from filtration) decanting and bottling (spillages and cleaning of vessels and bottles). Cleaning is not only done with water (cold or lukewarm) but also with solvents, detergents and chemical agents, such as sodium hydroxide. Each wine production step generates a varying amount of wastewater, with qualitative characteristics relevant to the process stage (Table 1) [63].

Winery wastewater overall is produced in high amounts; it has been calculated as $0.5-14$ litres per litre of wine produced [64], is mostly acidic, phytotoxic, with high biochemical oxygen demand (BOD) and bactericidal phenols. As can be easily assumed, the generation of wine demands vast amounts of water that have been estimated between 1 and 4 litres per litre of wine produced resulting into 26,000,000-100,500,000 hectolitres of water consumption globally per year [63], while less conservative calculations raise the number to $1,000,000,000$ hectolitres per annum in worldwide wine production [63, 65].

The unregulated, unmonitored release of winery wastewater to the soil and water streams can change their chemical and physical characteristics such as $\mathrm{pH}$, conductivity and colour, as well as having several other detrimental effects to the ecosystem. The high organic matter, indicated by BOD, chemical oxygen demand 
(COD) and total organic carbon (TOC), results in reduction of oxygen levels in the aquatic environment causing death of several aquatic organisms and generating odours due to the anaerobic decomposition [63]. High alkalinity or extreme acidity, indicated by the $\mathrm{pH}$, affects the solubility of ions and heavy metal content, thus making water toxic and influencing detrimentally both crops and marine organisms. Sodicity of soil-the high sodium content of soil-, indicated by sodium adsorption ratio (SAR), can cause disintegration of soil structure, resulting in surface crusting, which in turn causes low infiltration and hydraulic conductivity. On the other hand, high nutrient content such as $\mathrm{N}, \mathrm{K}$ and $\mathrm{P}$ leads to eutrophication and algal blooms, while the drinking water if containing nitrite and nitrate can be highly toxic to humans. High ionic content or salinity indicated by electrical conductivity (EC) and total dissolved solids (TDS) influences the palatability of water, its uptake by the crops, the flora as well as the wellbeing of fauna. High content in solids, indicated by total solids and total suspended solids (TS and TSS), can reduce light transmission, endangering the ecosystem's health and smothering its habitants [63].

The high organic and salts content and acidity of winery waste may cause plant growth inhibition, while alterations in conductivity result in retardation of germination, hindering the water uptake by the seeds [66]. Typical composition of winery wastewater is summarised in Table 2 and the elemental composition of solid winery waste grape marc is given in the Table 3 .

On the other hand, winery waste is generally biodegradable with a high BOD and COD (Table 5), due to carbohydrate and alcohol content and therefore constitutes a good candidate for fermentation feedstock, provided the use of acid tolerant microorganisms. Commonly the COD concentration of winery waste streams varies from 320 to $49,105 \mathrm{mg} \mathrm{L}^{-1}$ with a mean value of $11,886 \mathrm{mg} \mathrm{L}^{-1}$, while the BOD ranges between 203 and $22,418 \mathrm{mg} \mathrm{L}^{-1}$ with a mean value of $6570 \mathrm{mg} \mathrm{L}^{-1}$ [19].

\section{Applying the Biorefinery Idea Using Grape Winery Waste as Substrate}

The biorefinery concept was introduced to tackle the global energy crisis and climate change, attributed to the intensive industrialisation across the globe. Energy production is among the most polluting processes, based majorly on nonrenewable sources such as coal, oil and natural gas. On the other hand, the biorefinery concept was and still is majorly applied to cereals (crops such as wheat and corn) causing implications such as land competition, food shortages, and depletion of natural resources such as water and soil nutrients.

Nowadays, the concept has been extended to the formulation of a biobased economy that has been estimated to grow globally by 2020 to $\$ 250$ billion in value ( $\$ 77$ bn at $2005, \$ 125$ bn at 2010) generating up to 380,000 jobs (120,000 at 2005, 190,000 at 2010) However, currently biobased goods replace just $0.2 \%$ of petroleum-based goods, but alternatives exist for over $90 \%$ of them $[67,68]$. The prospect for scaling up has enlivened both supporters and critics of the technology $[49,50]$.

Table 1 Wine production stages in relation to generation of wastewater [63, 113, 114]

\begin{tabular}{|c|c|c|c|c|}
\hline Period & Season & Wine production process & Effect on wastewater characteristics & $\begin{array}{l}\text { Effect of } \\
\text { wastewater volume }\end{array}$ \\
\hline \multirow{2}{*}{$\begin{array}{l}\text { Pre- } \\
\text { harvest }\end{array}$} & \multirow{6}{*}{$\begin{array}{l}\text { Winter-Spring } \\
\text { (Jan-May) }\end{array}$} & Cleaning processes & & \\
\hline & & Alkali washing and neutralisation & Increase $(\uparrow)$ of $\mathrm{K}, \mathrm{COD}, \mathrm{pH}$ & Up by $33 \%$ \\
\hline $\begin{array}{l}\text { Early } \\
\text { harvest }\end{array}$ & & $\begin{array}{l}\text { Rinsing (tanks, floors, bottling, barrels } \\
\text { transfer lines, pipes etc.) }\end{array}$ & Increase $(\uparrow)$ of $\mathrm{P}, \mathrm{Cl}, \mathrm{COD}$ & Up by $43 \%$ \\
\hline \multicolumn{4}{|l|}{$\begin{array}{l}\text { Peak } \\
\text { harvest }\end{array}$} & \\
\hline \multicolumn{4}{|l|}{$\begin{array}{l}\text { Late } \\
\text { harvest }\end{array}$} & \\
\hline & & Clarification-maturation processes & & \\
\hline $\begin{array}{l}\text { Post- } \\
\text { harvest }\end{array}$ & $\begin{array}{l}\text { Summer-Winter } \\
\quad \text { (Jun-Dec) }\end{array}$ & Filtration & $\begin{array}{l}\text { Increase }(\uparrow) \text { of various contaminants, } \\
\text { COD, EC }\end{array}$ & Up by $15 \%$ \\
\hline \multirow[t]{4}{*}{$\begin{array}{l}\text { Non } \\
\text { harvest }\end{array}$} & & Stabilisation-acidification & $\begin{array}{l}\text { Increase }(\uparrow) \text { of chemicals such } \mathrm{SO}_{4} \text {, } \\
\mathrm{NaCl}, \mathrm{COD}, \mathrm{EC}, \mathrm{pH}\end{array}$ & Up by $3 \%$ \\
\hline & & Cooling & Increase $(\uparrow)$ of various salts, COD, EC & Up by $6 \%$ \\
\hline & & Other stages & & \\
\hline & & Winery practices & Increase $(\uparrow)$ various salts, $\mathrm{pH}, \mathrm{COD}$ & Up by $10 \%$ \\
\hline
\end{tabular}


Table 2 Typical composition of winery waste wastewater $[19,63,97,98]$

\begin{tabular}{lllll}
\hline Parameters & Unit & Min & Mean & Max \\
\hline pH & $\mathrm{mg} \mathrm{L}^{-1}$ & 2.5 & 5.3 & 12.9 \\
Total solids (TS) & & 190 & 8660 & 18,332 \\
Total suspended solids (TSS) & 66 & 1700 & 8600 \\
Total volatile solids (TVS) & 661 & 5625 & 12,385 \\
Chemical oxygen demand (COD) & 320 & 11,886 & 49,105 \\
Biochemical oxygen demand (BOD 5$)$ & 181 & 6750 & 22,418 \\
Total organic carbon (TOC) & & 41 & 1876 & 7363 \\
Total phosphorous (TP) & & 53 & 280 \\
Total nitrogen (TN) & & 10 & 118 & 415 \\
Total phenolic compounds (TPh) & & 0.51 & 205 & 1450 \\
Electrical conductivity (EC) & & 1.1 & 3.46 & 7.2 \\
\hline
\end{tabular}

Table 3 Indicative elemental composition of white and red grape marc (pomace) based on Romanian wine [60]

\begin{tabular}{lllllll}
\hline & \multicolumn{7}{l}{ Elemental composition (\%) } \\
\cline { 2 - 7 } & $\mathrm{C}$ & $\mathrm{H}$ & $\mathrm{O}$ & $\mathrm{N}$ & $\mathrm{S}$ & Ash \\
\hline White grape marc & 52.97 & 5.94 & 34.22 & 0.54 & 4.16 & 2.18 \\
Red grape marc & 41.21 & 5.93 & 45.50 & 0.66 & 3.24 & 3.46 \\
\hline
\end{tabular}

Economically, implementation of biorefinery into large scale has not always proven feasible, due to the high cost of feedstock production and processing [69, 70]. Several factors should be taken into account while estimating the feasibility of such a process (Fig. 6) Several attempts have been made to reduce the dependence on energy crops, involving the use of lignocellulosic material; however several complications regarding the cost of processing have arisen [71].

During the last decade the need for sophisticated treatment strategy of waste has emerged, due to the rise of environmental awareness, the continuously stringent rules applied on waste disposal and the elevated cost of the conventional waste treatments.

Waste can be seen as an inexhaustible resource due to its rich content in valuable nutrients, with agriculture waste (crops, plant and vegetation) related to food, feed and beverage production becoming a strong nominee as biorefinery feedstock. Agricultural waste complex physicochemical nature might require pre-treatment, however in the case of winery waste due to its generation process this need is minimised [72].

Both the solid and the liquid winery waste can be used successfully as feedstock for the production of high value chemicals either in a format of conventional biorefinery (lees, vinasses, marc) (Fig. 7) or as green (leafs, pomace) (Fig. 8) or a lignocellulosic (LCF) (Fig. 9) (stalks, peels, seeds, trimming vine shots, pips, pomace) biorefinery, where the effluent winery waste can be used as bioconversion feedstock. In the case of winery wastewater, the high content is organic matter expressed by the COD.

In a LCF biorefinery (Fig. 9) the hard fibrous plant parts (for example pomace, seeds, stalks or seeds) are fractionated, by enzymatic or chemical hydrolysis in three basic chemical parts namely (a) hemicellulose, pentoses, 5-C polymers, (b) cellulose, hexoses, 6-C polymers and (c) lignin, phenols. These fractions will be further converted to useful chemicals such as ethanol, carboxylic acids (acetic, butyric acid acetic acid), butanol, acetone and others [48, 73]. A biorefinery requires, nevertheless, a demanding capital investment and, if based in one major conversion technology, the cost of outputs for the consumers is increased. Therefore several conversion technologies (thermochemical, biochemical/biological chemical, biological) can be integrated (Fig. 8), so that the biorefinery will not only be limited to the production of chemicals but also include production of heat and electricity.

\section{Bioconversion of Grape Winery Waste to High Value Products and Energy}

\section{Case Studies}

The concept of biological treatment of wine waste has been applied extensively in wastewater treatment plants proving their biodegradability. Taking a step further, several case studies have been conducted over the past 15 years to apply bioconversions and biotransformations of winery waste and wastewater to high value products. These attempts, mostly practised in laboratory scale, have had varying success rates, however they have gone far beyond proving the concept and most of them have shown highly promising results. In these studies, wine lees, grape marc, vinasses, and winery wastewater have been used as feedstock to produce platform chemicals such as lactic acid, biofuels including ethanol, enzymes, chemical intermediates and energy through pyrolysis and anaerobic digestion. 


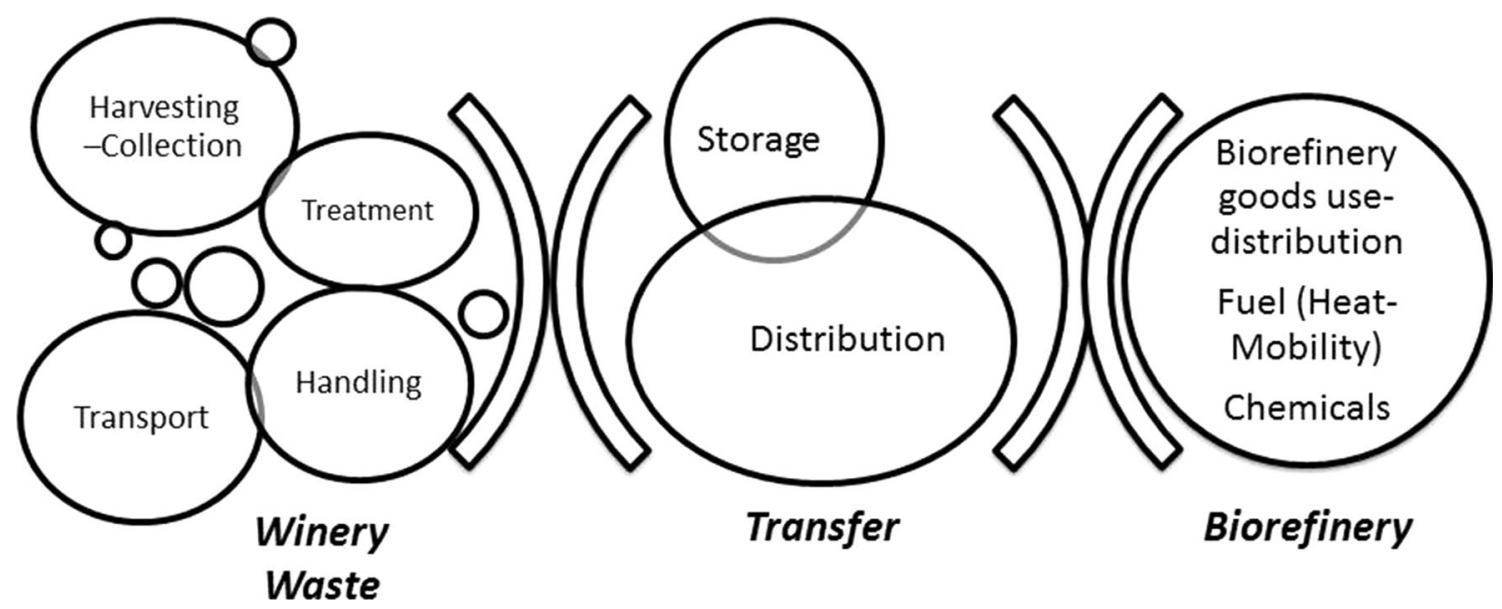

Fig. 6 Factors affecting the biorefinery concept applied on the winery waste

Fig. 7 The chemical/ biochemical biorefinery assortment applied to winery waste $[58,59,67,69,73,117]$

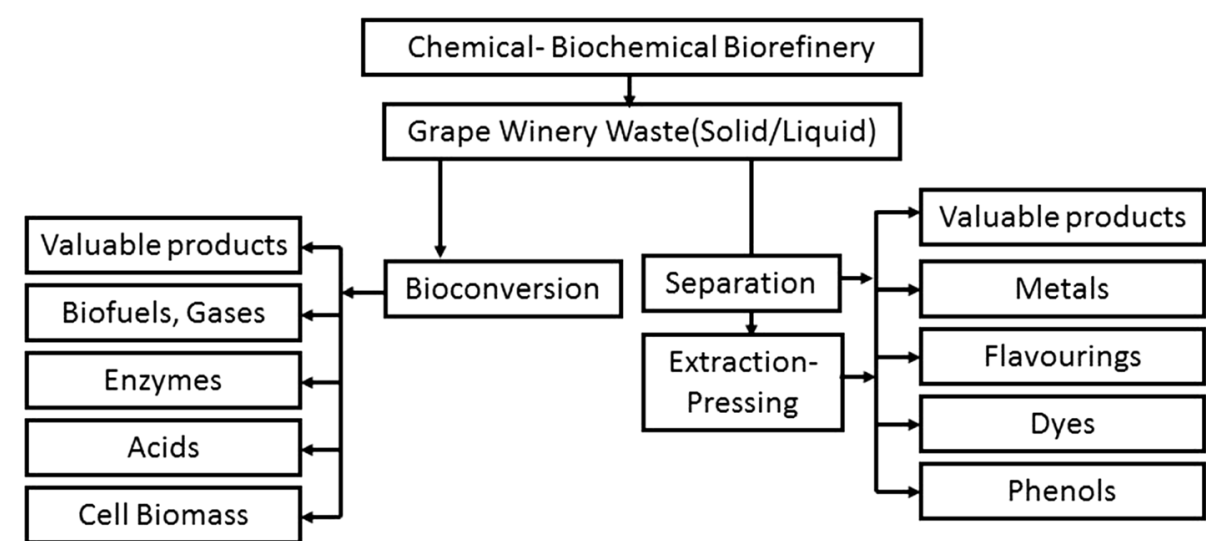

Fig. 8 The green biorefinery assortment applied to winery waste $[67,69,73,117]$

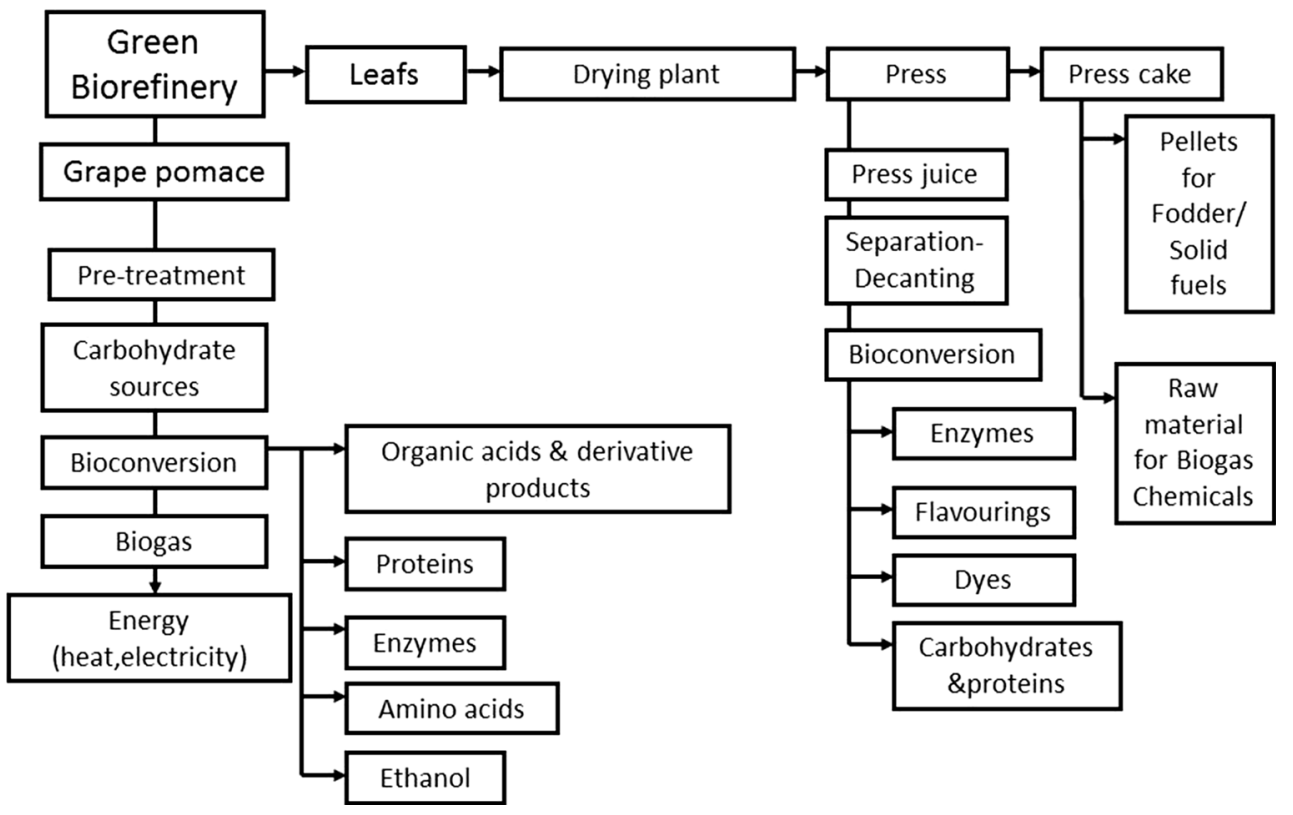


Fig. 9 The LFC biorefinery assortment applied to winery waste $[67,69,73,117]$

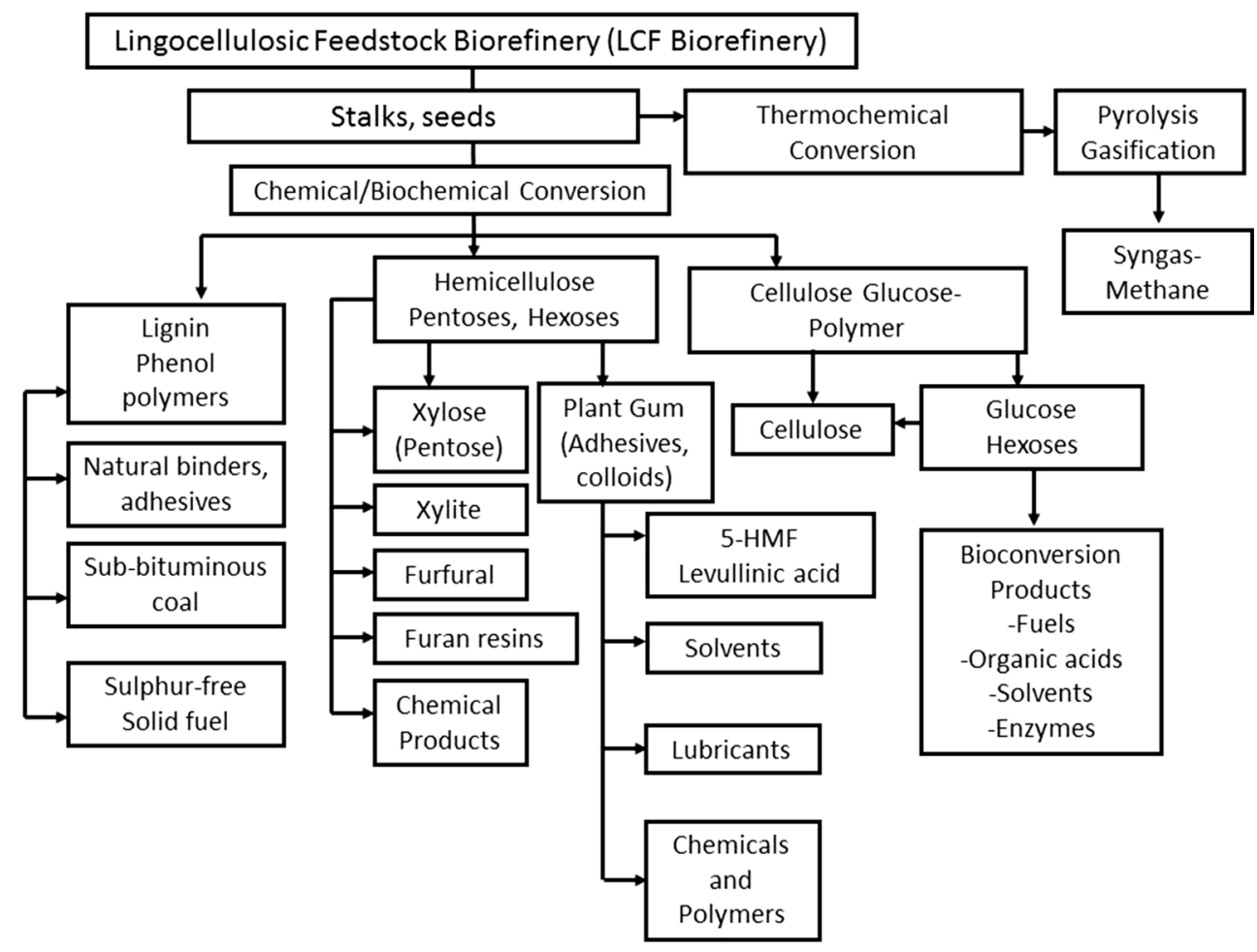

\section{Utilisation of Grape Marc and Vine Shoots as Substrate}

Grape marc is rich in hemicellulosic sugars that, if hydrolysed, will produce mixtures of xylose and glucose that could be under the presence of microorganisms converted to lactic acid. Numerous researchers [74-77] have used effectively $L$. pentosus and $L$. rhamnosus and it has been found that the production of biosurfactants is induced simultaneously with the production of lactic acid. The produced biosurfactants have been proven effective when tested on several non-hydrophilic plant based substrates $[20,78]$. Other studies include the use of grape seed oil for the production of rhamnolipid, a biosurfactant generated successfully from the propagation of Pseudomonas aeruginosa $\mathrm{J} 4$, while grape marc was used as substrate for lactobacilli spawned anti-allergic substances [74]. Grape marc has been also successfully used in solid state fermentations for the production of hydrolytic enzymes such as exo-polygalacturonase, xylanase, b-glucosidase, pectinase and cellullase [79-82], substances effective against allergies or bioethanol [83]. Efforts to recover phenols from grape marc, using ultrasound [84] and solvents (ethanol, methanol) [85] and supercritical fluid consecutive [86] extraction method, have been made with a high success rate.

Grape marc on its own or as a part of an agroindustrial substrate mixture has also been used effectively as an anaerobic digestion substrate for the generation of biogas and methane [87-89] and it is estimated that a smallmedium fully operational winery could produce $7800 \mathrm{~kW}$ h year ${ }^{-1}$ electrical and $8900 \mathrm{~kW} \mathrm{~h}$ year $^{-1}$ thermal energy. Further studies using grape marc for biotechnological production of goods are summarised in Table 4 .

To address the numerous difficulties (reduced financial resources, seasonal productivity, transportation costs, complex procedures) researchers [74] have suggested the use of grape marc as compost, even though the phytotoxic attributes of the waste demand extensive pre-treatment. A promising and possibly financially viable process which has been proposed entails a mixture of grape marc, grape stalks and vine shoots to be used as a substrate for growth of edible mushrooms Agaricus bisporus.

Other uses of grape marc include its use as a feed additive for livestock (pigs, goats, ewes). The global market value of feed additives has been estimated to reach by $2017 \$ 27.6$ billion, due to the expansion of meat and livestock production especially in developing counties. Grape marc has been found to improve sensory abilities and enhance the metabolism of livestock. Trials have been made by treating grape marc with fungi (Aspergillus, Rhizopus and Trichoderma ssp.) to enhance protein content in order to provide a nutritious animal feed (protein contents increase between 5 and $26 \%$ and digestibility increased from 25 to $50 \%$ ) [90].

A similar approach to the treatment of grape marc has been applied to vine shoots which, when pre-treated (hydrolysis), can be converted by fermentative 
Table 4 Biobased treatments of winery waste $[5,6,74]$

\begin{tabular}{|c|c|c|}
\hline Winery waste & Treatment & Product \\
\hline \multirow[t]{2}{*}{ Vinification lees } & - & Nutritional supplement for lactobacilli \\
\hline & Extraction of tartaric acid & $\begin{array}{l}\text { Nutritional supplement for } \\
\text { Debaromyces hansenii }\end{array}$ \\
\hline \multirow[t]{3}{*}{ Vinasses } & Alkali treatment, microwave, fermentation & Lactic acid \\
\hline & Solubilisation and precipitation & Tartaric acid \\
\hline & Fermentation & Protein rich fungal biomass \\
\hline Lees, grape marc & Yeast induced fermentation & Protein \\
\hline $\begin{array}{l}\text { Vinasses and grape } \\
\text { marc }\end{array}$ & Fermentation with Trichoderma viride & Biocontrol agent \\
\hline \multirow{5}{*}{$\begin{array}{l}\text { Trimming vine } \\
\text { shoots }\end{array}$} & Hydrolysis, fermentation of hemicellulosic sugars by L. pentosus & Lactic acid, biosurfactants \\
\hline & $\begin{array}{l}\text { Hydrolysis, delignification, simultaneous saccharification and fermentation of } \\
\text { cellulosic fraction }\end{array}$ & Lactic acid \\
\hline & $\begin{array}{l}\text { Hydrolysis and fermentation of hemicellulosic sugars with Lactobacillus and } \\
\text { Debaryomyces hansenii }\end{array}$ & Lactic acid; xylitol; biosurfactants \\
\hline & Solid state fermentation with Pleurotus & Source of microbial and human food \\
\hline & Hydrolysis, fermentation of hemicellulosic sugars by L. pentosus & Lactic acid, biosurfactants \\
\hline \multirow[t]{5}{*}{ Grape marc } & Hydrolysis, fermentation L. pentosus & Lactic acid, biosurfactants \\
\hline & Extraction & $\begin{array}{l}\text { Tannins as wood adhesives, } \\
\text { Polyphenols }\end{array}$ \\
\hline & Solid state fermentation & Hydrolytic enzymes \\
\hline & Fermentation with lactobacilli & Anti-allergens \\
\hline & Solid state fermentation & Hydrolytic enzymes, bioethanol \\
\hline Grape marc, lees & Yeast-induced fermentation & Protein \\
\hline Grape seed oil & Fermentation with Pseudomonas aeruginosa & Biosurfactants \\
\hline Grape marc seed & Extraction & Oil \\
\hline
\end{tabular}

microorganisms into chemicals such as xylitol, ethanol, lactic acid and biosurfactants [91-93]. Bacillus tequilensis has been grown successfully on pre-treated vine shoots (enzymatic, alkaline hydrolysis) generating approximately $1.52 \mathrm{~g} \mathrm{~L}^{-1}$ of biosurfactants [94]. Debaryomyces hansenii NRRL Y-7426 and L. rhamnosus co-cultures, propagated on vine trimming wastes, have been used to generate biosurfactants and xylitol at $27.5 \mathrm{~g} \mathrm{~L}^{-1}$ [95].

Lactobacillus pentosus [96] and other microorganisms have been successfully used to produce lactic acid from vine shoot samples treated with water and acid to an amount of $24.5 \mathrm{~g} \mathrm{~L}^{-1}$, as well as to produce a mixture of xylooligosaccharides and single sugars [97, 98]. Co-cultures of L. pentosus and L. plantarum have been utilised to produce $43.0 \mathrm{~g} \mathrm{~L}^{-1}$ of lactic acid, $1.58 \mathrm{mM}$ of polylactic acid and $2.6 \mathrm{mg} \mathrm{L}^{-1}$ of biosurfactants from trimming vine shoot hydrolysates [99].

Although not a direct use in the concept of a biorefinery, vine shoots can be effectively used as crude material for pulp paper production, in sites of abundant vineyards such as Spain [2, 100]. The main products produced of trimming vine shoots are summarized in Table 4; most of the cited studies involve the production of lactic acid, biosurfactants, cellulose, pulp and phenolic compounds (Table 5).
Table 5 Indicative composition of COD in winery wastewater $[115,116]$

\begin{tabular}{lrl}
\hline & Concentration $\left(\mathrm{mg} \mathrm{L}^{-1}\right)$ & Composition (\%) \\
\hline COD (dissolved) & 12,700 & 100 \\
Ethanol & 4900 & 80.3 \\
Carbohydrates (glucose-fructose) & 870 & 7.3 \\
Glycerol & 320 & 3.1 \\
Tartaric acid & 1260 & 5.3 \\
Malic acid & 70 & 0.4 \\
Lactic acid & 160 & 1.2 \\
Acetic acid & 300 & 2.6 \\
\hline
\end{tabular}




\section{Utilisation of Vinasse as Substrate}

The products obtained from vinasse, in most of the cited studies (Table 4), involve the production of nutritional microbial media, tartaric acid, protein rich biomass and plant growth substrates [101, 102]. It has been reported that non treated vinification lees may be used either alone or combined with other cheap waste products, such as corn steep liquor, to formulate inexpensive nutrient media to be used for fermentative production of lactic acid or xylitol [103]. The production of xylitol, when using the liquid fraction of white wine lees, reached $31.9 \mathrm{~g} \mathrm{~L}^{-1}$, while on the solid fraction $22.5 \mathrm{~g} \mathrm{~L}^{-1}$ were produced [104].

Vinasse, pre-treated with alkali solutions and microwaving prior to fermentation, has been used as feedstock for the successful production of lactic acid. Lactic acid production was achieved at approximately $17.5 \mathrm{~g} \mathrm{~L}^{-1}$. The pre-treatment step is enhancing the rate of conversion of pre-processed vinasse to lactic acid and the utilization rate of cellulose and hemi-cellulose can reach values around 23.8 and $71 \%$, respectively [105].

Other uses of vinasse include the production of protein rich fungal biomass, as an aquaculture feed ingredient [74], and the production of single cell protein $(\mathrm{SCP}) \mathrm{A}$ combination of vinasses and trimming vine shoots has also been used successfully for the production of lactic acid and surfacing, a biosurfactant at a final total concentration (hemicellulosic and liquid fraction) of $25.1 \mathrm{~g} \mathrm{~L}^{-1}$ and $3.2 \mathrm{mg} \mathrm{L}^{-1}$ respectively [106].

From vinasses, tartaric acid can be effectively recovered. Tartaric acid is widely applied in the food and beverage industry as natural acid preservative and an alternative to the citric and phosphoric acids. Grape distilled lees, from which tartaric acid has been recovered using chemical extraction, have been freeze dried and used as a nutrient medium for Lactobacillus pentosus growth [107], achieving a lactic acid production of $18.9 \mathrm{~g} \mathrm{~L}^{-1}$ [61, 62]. Although researchers [108] have identified this, they have used methods based on chemical extraction (treatment with $\mathrm{HCl}$ and precipitation with $\mathrm{CaCl}_{2}$ generating 1:2 ratio) that may be ineffective in terms of waste generation.

\section{Utilisation of Grape Winery Wastewater as Substrate}

Winery wastewater, i.e. the post cleaning operation (crushing, pressing etc.) wastewater, has not been widely used as biotechnological conversion feedstock [109, 119]. Limited studies have been conducted, with winery wastewater being used as substrate for Gluconacetobacter xylinus for the production of cellulose at a $6.26 \mathrm{~g} \mathrm{~L}^{-1}$ $[110,111]$. Other studies involve the use of fungi,
Trichoderma viride, Aspergillus niger and Aspergillus oryzae for the production of SCP at a $5 \mathrm{~g} \mathrm{~L}^{-1}$ and a simultaneous reduction of COD to $90 \%$ [112].

The vast majority of waste distilleries have been treated using traditional wastewater treatment processes, such as land spreading or anaerobic digestion, with the focus being the treatment on BOD and COD, rather than the production of energy or platform chemicals.

\section{Conclusions}

Winery waste can be successfully used as feedstock in the biorefinery concept. The seasonal availability of the waste, however, demands judicious handling and treatment to achieve economic feasibility and efficiency. Further research and practical experimentation is necessary since, in the case of winery waste, limited studies have been conducted and life cycle analysis regarding full economic costing of the use wine waste as a resource is needed. The currently available results on the biotechnological use of winery waste are a promising alternative to the current treatment techniques that are focusing on the waste remediation and treatment, rather than resource recovery.

Acknowledgments This work has benefited from the helpful comments of Dr Anna Charalambidou, Lecturer in English Languageat Middlesex University London.

Open Access This article is distributed under the terms of the Creative Commons Attribution 4.0 International License (http://crea tivecommons.org/licenses/by/4.0/), which permits unrestricted use, distribution, and reproduction in any medium, provided you give appropriate credit to the original author(s) and the source, provide a link to the Creative Commons license, and indicate if changes were made.

\section{References}

1. Kierath, T., Wang, C.: The Global Wine Industry, Slowly Moving from Balance to Shortage. Morgan Stanley Research, London (2013)

2. Italian Chamber of Commerce in New Zealand Inc (ICCNZ): Market Profile for Wine in Continental Europe, pp. 1-14. New Zealand Trade and Enterprise, London (2008)

3. Lin, C.S.K., et al.: Current and future trends in food waste valorization for the production of chemicals, materials and fuels: a global perspective. Biofuels Bioprod. Bioref. 8, 686-715 (2014)

4. Mirabella, N., Castellani, V., Sala, S.: Current options for the valorization of food manufacturing waste: a review. J. Clean. Prod. 65, 28-41 (2014)

5. Arvanitoyannis, I.S., Ladas, D., Mavromatis, A.: Potential uses and applications of treated wine waste: a review. Int. J. Food Sci. Technol. 41, 475-487 (2006)

6. Arvanitoyannis, I.S., Ladas, D., Mavromatis, A.: Wine waste treatment methodology. Int. J. Food Sci. Technol. 41, 1117-1151 (2006) 
7. Bustamante, M.A., Moral, R., Paredes, C., Perez-Espinosa, A., Moreno-Caselles, J., Perez-Murcia, M.D.: Agrochemical characterisation of the solid by-products and residues from the winery and distillery industry. Waste Manag. 28, 372-380 (2008)

8. Bustamante, M.A., Paredes, C., Moral, R., Moreno-Caselles, J., Perez-Espinosam, A., Perez-Murcia, M.D.: Uses of winery and distillery effluents in agriculture: characterisation of nutrient and hazardous components. Water Sci. Technol. 51, 145-151 (2005)

9. Mosse, K.P.M., Patti, A.F., Christen, E.W., Cavagnaro, T.R.: Review: winery wastewater quality and treatment options in Australia. Australas. J. Grape Wine Res. 17, 111-122 (2011)

10. Appels, L., Baeyens, J., Degrève, J., Dewil, R.: Principles and potential of the anaerobic digestion of waste-activated sludge. Progr. Energy Comb. Sci. 34, 755-781 (2008)

11. Frenkel, V.S., Cummings, G., Maillacheruvu, K.Y., Tang, W.Z.: Food-processing wastes. Water Environ. Res. 85, 1501-1514 (2013)

12. Zacharof, M.-P., Lovitt, R.W.: Adding value to wastewater by resource recovery and reformulations growth media: current prospects and potential. J. Water Reuse Desalin. 5, 473-479 (2015)

13. Zacharof, M.-P., Lovitt, R.W.: The filtration characteristics of anaerobic digester effluents employing cross flow ceramic membrane microfiltration for nutrient recovery. Desalination 341, 27-37 (2014)

14. Hatti-Kaul, R., Tornvall, U., Gustafsson, L., Borjesson, P.: Industrial biotechnology for the production of bio-based chemicals-a cradle-to-grave perspective. Trends Biotechnol. 25, 119-124 (2007)

15. Østergaard, P.A.: Comparing electricity, heat and biogas storages' impacts on renewable energy integration. Energy 37, 255-262 (2012)

16. The Biocomposites Centre: The Biorefining Opportunities in Wales: From Plants to Products. In: Bangor (2011)

17. Wadhwa, M., Bakshi, M.P.S., Makkar, H.P.S.: Utilization of Fruit and Vegetable Wastes as Livestock Feed and as Substrates for Generation of Other Value-Added Products, pp. 1-56. Food and Agriculture Organization of the United Nations (FAO), Rome (2013)

18. de Villiers, A., Albertsa, P., Tredouxb, A.G.J., Nieuwoudtb, H.H.: Analytical techniques for wine analysis: an African perspective; a review. Anal. Chim. Acta 730, 2-23 (2012)

19. Ioannou, L.A., Li Puma, G., Fatta-Kassinos, D.: Treatment of winery wastewater by physicochemical, biological and advanced processes: a review. J. Hazard Mater. 286, 343-368 (2014)

20. Christ, K.L.: Water management accounting and the wine supply chain: empirical evidence from Australia. Br. Acc. Rev. 46, 379-396 (2014)

21. Morley, N., Bartlett, C.: Mapping Waste in the Food Industry. Defra, Food and Drink Federation, UK (2008)

22. Holmes, C., et al.: The UK Anaerobic Digestion Market. UK Green Investment Bank, Edinbrugh (2015)

23. Tyagi, V.-K., Lo, S.-L.: Sludge: a waste or renewable source for energy and resources recovery? Renew. Sustain. Energy Rev. 25, 708-728 (2013)

24. Zacharof, M.-P., Mandale, S.J., Williams, P.M., Lovitt, R.W.: Nanofiltration of treated digested agricultural wastewater for recovery of carboxylic acids. J. Clean. Prod. 112, 4749-4761 (2016)

25. European Comission: Directive of the European Parliament and of the Council amending Directives 2008/98/EC on Waste, 94/62/EC on Packaging and Packaging Waste, 1999/31/EC on the Landfill of Waste, 2000/53/EC on End-of-Life Vehicles, 2006/66/EC on Batteries and Accumulators and Waste Batteries and Accumulators, and 2012/19/EU on Waste Electrical and Electronic Equipment (2014)

26. The Carbon Plan: Delivering our low carbon future presented to Parliament pursuant to sections 12 and 14 of the Climate Change Act 2008 amended 2nd December 2011 from the version laid before Parliament on 1st December 2011. In: Department of Energy \& Climate Change (ed.) HM Government, London (2011)

27. Waste water treatment in the United Kingdom-2012 Implementation of the European Union Urban Waste Water Treatment Directive-91/271/EEC. In: Department for Environment, F.A.R.A. (ed.) Department for Environment, Food and Rural Affairs, London (2012)

28. Waste Management Plan for England. Department for Environment Food and Rural Affairs UK, London (2013)

29. Review of Waste Policy and Legislation EU Waste Framework Directive 2008/98/EC, the Landfill Directive 1999//31/EC and the Packaging and Packaging Waste Directive 94/62/EC. In: Waste-Environment-European Commission, Brussels (2014)

30. Zacharof, M.-P., Lovitt, R.W.: Complex effluent streams as a potential source of volatile fatty acids. Waste Biom. Valor. 4, 557-581 (2013)

31. Zacharof, M.-P., Vouzelaud, C., Lovitt, R.W. (eds.): The Use of Membrane Technology for the Formulation of Spent Anaerobic Digester Effluents as Nutrient Source for Bacterial Growth. WIT Press, Southampton (2014)

32. Zacharof, M.-P., Vouzelaud, C., Mandale, S.J., Lovitt, R.W.: Valorization of spent anaerobic digester effluents through production of platform chemicals using Clostridium butyricum. Biom. Bioenergy 81, 294-303 (2015)

33. Dimakis, A., et al.: Methods and tools to evaluate the availability of renewable energy sources. Renew. Sustain. Energy Rev. 15, 1182-1200 (2011)

34. DECC (Department of Energy and Climate Change website): Increasing the Use of Low Carbon Technologies. (2014). http:// www.gov.uk/government/policies/increasing-the-use-oflow-car bon-technologies. Accessed 19 May 2016

35. Kiely, G.: Environmental Engineering. McGraw-Hill, Maidenhead (1997)

36. Tchobanoglous, G., Burton, L.F., Stensel, D.H.: Wastewater Engineering, Treatment and Reuse. MacGraw-Hill, Singapore (2004)

37. Wang, Z., Yu, H., Ma, J., Zheng, X., Wu, Z.: Recent advances in membrane bio-technologies for sludge reduction and treatment. Biotechnol. Adv. 31, 1187-1199 (2013)

38. Fernando, S., Adhikari, S., Chandrapal, C., Murali, N.: Biorefineries: current status, challenges, and future direction. Energy Fuels 20, 1727-1737 (2006)

39. Geoffrey, S., Simate, G., Cluett, J., Lyuke, S.E., Musapatika, E.T., Ndlovu, S., Walubita, L.F., Alvarez, A.E.: The treatment of brewery wastewater for reuse: state of the art. Desalination 273, 235-247 (2011)

40. Jones, E., Salin, V., Williams, G.W.: Nisin and the Market for Commercial Bacteriocins. Consumer and Product Research Report, vol. CP-01-05, pp. 1-20. Texas Agribusiness Market Research Center (TAMRC) (2005)

41. Cave, S.: Anaerobic Digestion Across the UK and Europe. Nothern Ireland Assembly (2013)

42. Jefferson, M.: Accelerating the transition to sustainable energy systems. Energy Policy 36, 4116-4125 (2008)

43. Li, W.-W., Yu, H.-Q.: From wastewater to bioenergy and biochemicals via two-stage bioconversion processes: a future paradigm. Biotechnol. Adv. 29, 972-982 (2011)

44. Zacharof, M.-P., Lovitt, R.W.: Recovery of volatile fatty acids (VFA) from complex waste effluents using membranes. Water Sci. Technol. 69, 495-503 (2014) 
45. Angenent, L.T., Karim, K., Muthanna, H.A.-D., Wrenn, B.A., Espinosa-Domiguez, R.: Production of bioenergy and biochemicals from industrial and agricultural wastewater. Trends Biotechnol. 22, 477-485 (2004)

46. Lin, Y., Tanaka, S.: Ethanol fermentation from biomass resources: current state and prospects. Appl. Microb. Biotechnol. 69, 627-642 (2006)

47. Zacharof, M-.P., Lovitt, R.W.: Economic liquid growth medium development for high-rate production of cellular biomass and lactic acid of Lactococcus lactis. In: Méndez-Vilas, A.(ed.) Industrial, Medical and Environmental Applications of Microorganisms: Current Status and Trends, pp. 419-424. Wageningen Academic Publishers, Wageningen (2014)

48. Sadhukhana, J., Mustafa, M.A., Misailidis, N., Mateos-Salvadora, F., Dub, C., Campbell, G.M.: Value analysis tool for feasibility studies of biorefineries integrated with value added production. Chem. Eng. Sci. 63, 503-519 (2008)

49. Petre, M.: Advances in Applied Biotechnology, 1st edn. InTech, Rijeka (2011)

50. Richardson, B.: From a fossil-fuel to a biobased economy: the politics of industrial biotechnology. Environ. Plan. C: Gov. Policy 30, 282-296 (2012)

51. Kythreotou, N., Tassou, S.A., Florides, G.: An assessment of the biomass potential of Cyprus for energy production. Energy 47, 253-261 (2012)

52. Musee, N., Lorenzen, L., Aldrich, C.: Decision support for waste minimization in wine-making processes. Environ. Prog. 25, 56-63 (2006)

53. Moletta, R.: Winery and distillery wastewater treatment by anaerobic digestion. Water Sci. Technol. 51, 137-144 (2005)

54. Melamane, X.L., Strong, P.J., Burgess, J.E.: Treatment of wine distillery wastewater: a review with emphasis on anaerobic membrane reactors. S. Afr. Soc. Enol. Vitic. 28, 25-36 (2007)

55. Dillon, C.: Waste Management in the South African Wine Industry. Cape Wine Academy, Midrand (2011)

56. Broome, J.C., Warner, K.D.: Agro-environmental partnerships facilitate sustainable wine-grape production and assessment. Calif. Agric. 62, 133-141 (2008)

57. Barrantes Leiva, M., Hosseini Koupaie, E., Eskicioglu, C.: Anaerobic co-digestion of wine/fruit-juice production waste with landfill leachate diluted municipal sludge cake under semicontinuous flow operation. Waste Manag 34, 1860-1870 (2014)

58. Begalli, D., Codurri, S., Gaeta, D.: Bio-energy from winery byproducts: a new multifunctional tool for the Italian wine districts. Paper presented at the 113th EAAE Seminar: The Role of Knowledge, Innovation and Human Capital in Multifunctional Agriculture and Territorial Rural Development, Belgrade, Republic of Serbia

59. Nerantzis, E.T., Tataridis, P.: Integrated enology-utilization of winery by-products into high added value products. e-J. Sci. Technol. 1, 79-89 (2006)

60. Ciuta, M.S., Mărculescu, C., Dincă, C., Badea, A.: Primary characterization of wine making and oil refining industry wastes. Buletin Stiintific - Universitatea Politehnica din Bucuresti, Series C 73, 307-320 (2011)

61. Pérez-Bibbins, B., Agrasar-Torrado, A., Pérez-Rodríguez, N., Aguilar-Uscanga, M.G., Domínguez, J.M.: Evaluation of the liquid, solid and total fractions of beer, cider and wine lees as economic nutrient for xylitol production. J. Chem. Technol. Biotechnol. 90, 1027-1039 (2015)

62. Pérez-Bibbins, B., Torrado-Agrasar, A., Salgado, J.M., Pinheiro de Souza Oliveira, R., Domínguez, J.M.: Potential of lees from wine, beer and cider manufacturing as a source of economic nutrients: an overview. Waste Manag. 40, 72-81 (2015)

63. Conradie, A., Sigge, G.O., Cloete, T.E.: Influence of winemaking practices on the characteristics of winery wastewater and water usage of wineries. S. Afr. Soc. Enol. Vitic. 35, 10-19 (2014)

64. Ene, S.A., Teodosiu, C., Robu, B., Volf, I.: Water footprint assessment in the winemaking industry: a case study for a Romanian medium size production plant. J. Clean. Prod. 43, 122-135 (2013)

65. Naziri, E., Nenadis, N., Mantzouridou, F.T., Tsimidou, M.Z.: Valorization of the major agrifood industrial by-products and waste from Central Macedonia (Greece) for the recovery of compounds for food applications. Food Res. Int. 65, 350-358 (2014)

66. Mateo, J.J., Maicas, S.: Valorization of winery and oil mill wastes by microbial technologies. Food Res. Int. (2015). doi:10. 1016/j.foodres.2015.03.007

67. Taylor, G.: Biofuels and the biorefinery concept. Energy Policy 36, 4406-4409 (2008)

68. Perimenis, A., Walimwipi, H., Zinoviev, S., Muller-Langer, F., Miertus, S.: Development of a decision support tool for the assessment of biofuels. Energy Policy 39, 1782-1793 (2011)

69. Bridgwater, A.V., Chinthapalli, R., Smith, P.W.: Bioref-integ FP7 EU Development of Advanced Biorefinery Schemes to be Integrated Into Existing Industrial Fuel Producing Complexes Project Report (2015). www.bioref-integ.eu. Accessed 15/08/ 2016

70. Kelly, J.M., Jin, B.: Wine industry residues. In: Nigam, P.S., Pandey, A. (eds.) Biotechnology for Agro-Industrial Residues Utilisation, pp. 293-311. Springer, Netherlands (2009)

71. Kiran, E.U., Trzcinski, A.P., Ng, W.J., Liu, Y.: Bioconversion of food waste to energy: a review. Fuel 134, 389-399 (2014)

72. Bai, Z., Jin, B., Li, Y., Chen, J., Li, Z.: Utilization of winery wastes for Trichoderma viride biocontrol agent production by solid state fermentation. J. Environ. Sci. 20, 353-358 (2008)

73. Luguel, C.: European Biorefinery Joint Strategic Research Roadmap for 2020 Strategic Targets for 2020 - Collaboration Initiative on Biorefineries in Europe (2011)

74. Devesa-Rey, R., Vecino, X., Varela-Alende, J.L., Barral, M.T., Cruz, J.M., Moldes, A.B.: Valorization of winery waste vs. the costs of not recycling. Waste Manag. 31, 2327-2335 (2011)

75. Bustos, G., Moldes, A.B., Cruz, J.M., Domínguez, J.M.: Influence of the metabolism pathway on lactic acid production from hemicellulosic trimming vine shoots hydrolyzates using Lactobacillus pentosus. Biotechnol. Prog. 21, 793-798 (2005)

76. Bustos, G., Moldes, A.B., Cruz, J.M., Domínguez, J.M.: Evaluation of vinification lees as a general medium for Lactobacillus strains. J. Agric. Food Chem. 52, 5233-5239 (2004)

77. Bustos, G., Moldes, A.B., Cruz, J.M., Domínguez, J.M.: Production of lactic acid from vine-trimming wastes and viticulture lees using a simultaneous saccharification fermentation method. J. Sci. Food Agric. 85, 466-472 (2005)

78. Portilla Rivera, O.M., Moldes, A.B., Torrado, A.M., Domınguez, J.M.: Lactic acid and biosurfactants production from hydrolyzed distilled grape marc. Process. Biochem. 42, 1010-1020 (2007)

79. Vorobieva, E.: Valorization of Grape Pomace Residues Integrating Hot Compressed Water with Biotechnology. Faculdade De Ciencias E Tecnologia Da Universidade Nova De Lisboa (2013)

80. Belén Díaz, A., de Ory, I., Caro, I., Blandino, A.: Enhance hydrolytic enzymes production by Aspergillus awamori on supplemented grape pomace. Food Bioprod. Process. 90, 72-78 (2012)

81. Salgado, J.M., Abrunhosa, L., Venancio, A., Domínguez, J.M., Belo, I.: Combined bioremediation and enzyme production by Aspergillus sp. in olive mill and winery wastewaters. Int. Biodeterior. Biodegrad. 110, 16-23 (2016)

82. Sanchez, S.R., Gil Sanchez, I., Arevalo-Villena, M., Perez, A.B.: Production and immobilization of enzymes by solid-state 
fermentation of agroindustrial waste. Bioprocess Biosyst. Eng. 35, 587-593 (2015)

83. Weber, M.M., Bahner, M.: Pollution Prevention for the Wine Industry. Research Triangle Institute, North Carolina (1999)

84. Goula, A.M., Thymiatis, K., Kaderides, K.: Valorization of grape pomace: drying behavior and ultrasound extraction of phenolics. Food Bioprod. Process. (2016). doi:10.1016/j.fbp. 2016.06.016

85. Guerrero, M.S., Torres, J.S., Nunez, M.J.: Extraction of polyphenols from white distilled grape pomace: optimization and modelling. Biores. Technol. 99, 1311-1318 (2008)

86. Aizpurua-Olaizola, O., et al.: Optimization of supercritical fluid consecutive extractions of fatty acids and polyphenols from vitis vinifera grape wastes. J. Food Sci. (2015). doi:10.1111/17503841.12715

87. Da Ros, C., Cavinato, C., Bolzonella, D., Pavan, P.: Renewable energy from thermophilic anaerobic digestion of winery residue: preliminary evidence from batch and continuous lab-scale trials. Biomass Bioenergy 91, 150-159 (2016)

88. Fabbri, A., Bonifazi, G., Serranti, S.: Micro-scale energy valorization of grape marcs in winery production plants. Waste Manag 36, 156-165 (2015)

89. Pellera, F.-M., Gidarakos, E.: Effect of substrate to inoculum ratio and inoculum type on the biochemical methane potential of solid agroindustrial waste. J. Environ. Chem. Eng. 4, 3217-3229 (2016)

90. Jin, B., Zepfa, F., Bai, Z., Gaoc, B., Zhuda, N.: A biotechsystematic approach to select fungi forbioconversion of winery biomass wastes to nutrient-rich feed. Process. Saf. Environ. Prot. 103, 60-68 (2016)

91. Corbin, K.R., et al.: Grape marc as a source of carbohydrates for bioethanol: chemical composition, pre-treatment and saccharification. Biores. Technol. 193, 76-83 (2015)

92. Mateo, J.J., Maicas, S.: Valorization of winery and oil mill wastes by microbial technologies. Food Res. Int. 73, 13-25 (2015)

93. Moldes, A.B., Bustos, G., Torrado, A., Domínguez, J.M.: Comparison between different hydrolysis processes of vinetrimming waste to obtain hemicellulosic sugars for further lactic acid conversion. Appl. Biochem. Biotechnol. 143, 244-256 (2007)

94. Cortés-Camargoa, S., Pérez-Rodríguezb, N., de Souza Oliveirad, R.P., Barragán Huertaa, B.E., Domínguez, J.M.: Production of biosurfactants from vine-trimming shoots using thehalotolerant strain Bacillus tequilensis ZSB10. Ind. Crops Prod. 79, 258-266 (2016)

95. Rivas, B., Torrado, A., Rivas, S., Moldes, A.B., Domínguez, J.M.: Simultaneous lactic acid and xylitol production from vine trimming wastes. J. Sci. Food Agric. 87, 1603-1612 (2007)

96. Bustos, G., de la Torre, N., Moldes, A.B., Cruz, J.M., Dominguez, J.M.: Revalorization of hemicellulosic trimming vine shoots hydrolyzates trough continuous production of lactic acid and biosurfactants by L. pentosus. J. Food Eng. 78, 405-412 (2007)

97. Vlyssides, A.G., Barampouti, E.M., Mai, S.: Wastewater characteristics from Greek wineries and distilleries. Water Sci. Technol. 51, 53-60 (2005)

98. Vlyssides, A.G., Barampouti, E.M., Mai, S., Stamatoglou, A., Tsimas, E.: Alternative biological systems for the treatment of vinasse from wine. Water Sci. Technol. 62, 2899-2904 (2010)

99. Rodríguez-Pazo, N., Salgado, J.M., Cortés-Diéguez, S., Domínguez, J.M.: Biotechnological production of phenyllactic acid and biosurfactants from trimming vine shoot hydrolyzates by microbial coculture fermentation. Appl. Biochem. Biotechnol. 169, 2175-2188 (2013)
100. Zheng, Y., et al.: Ensilage and bioconversion of grape pomace into fuel ethanol. J. Agric. Food Chem. 60, 11128-11134 (2013)

101. García-Lomillo, J., et al.: Antioxidant and antimicrobial properties of wine byproducts and their potential uses in the food industry. J. Agric. Food Chem. 62, 12595-12602 (2014)

102. Pavlou, A., Ritzoulis, C., Filotheou, A., Panayiotou, C.: Emulsifiers extracted from winery waste. Waste Biomass Valor. 7, 533-542 (2016)

103. Galanakis, C.M.: Recovery of high added-value components from food wastes: conventional, emerging technologies and commercialized applications. Trends Food Sci. Technol. 26, 68-87 (2012)

104. Bustos, G., Moldes, A.B., Cruz, J.M., Domınguez, J.M.: Production of fermentable media from vine-trimming wastes and bioconversion into lactic acid by Lactobacillus pentosus. J. Sci. Food Agric. 84, 2105-2112 (2004)

105. Tuck, C., Pérez, E., Horváth, I.T., Sheldon, R.A., Poliakoff, M.: Valorization of biomass: deriving more value from waste. Science 337, 695-700 (2012)

106. Rodriguez, N., Torrado, A., Cortes, S., Domínguez, J.M.: Use of waste materials for Lactococcus lactis development. J. Sci. Food Agric. 90, 1726-1734 (2010)

107. Rivas, B., Torrado, A., Moldes, A.B., Domínguez, J.M.: Tartaric acid recovery from distilled lees and use of the residual solid as an economic nutrient for Lactobacillus. J. Agric. Food Chem. 54, 7904-7911 (2006)

108. Tsolakis, N.K., Keramydas, C.A., Toka, A.K., Aidonis, D.A., Iakovou, E.T.: Agrifood supply chain management: a comprehensive hierarchical decision-making framework and a critical taxonomy. Biosyst. Eng. 120, 47-64 (2014)

109. Pant, D., Alok Adholeya, A.: Biological approaches for treatment of distillery wastewater: a review. Bioresour. Technol. 98, 2321-2334 (2007)

110. Wu, J.-M., Liu, R.-H.: Cost-effective production of bacterial cellulose in static cultures using distillery wastewater. J. Biosci. Bioeng. 115, 284-290 (2013)

111. Krzywonos, M., Cibis, E., Miśkiewicz, T., Ryznar-Luty, A.: Utilization and biodegradation of starch stillage (distillery wastewater) El. J. Biotechnol. 12, 1-12 (2009)

112. Zhang, Z.Y., Jin, B., Bai, Z.H., Wang, X.Y.: Production of fungal biomass protein using microfungi from winery wastewater treatment. Biores. Technol. 99, 3871-3876 (2008)

113. Van Schoor, L., Rossouw, J.: Winery Wastewater and Solid Waste Management, p. 5. WineLand Media, WineLand (2004)

114. EPA (Environmental Protection Authority): Review of the Opportunities of the Re-use of Winery Industry Solid Wastes. Report: ABN80078004798, Australia (2001)

115. Fillaudeau, L., Bones, A., Decloux, M.: Brewing, winemaking and distilling: an overview of wastewater treatment and utilisation schemes. In: Klemes, J., Smith, R., Kim, J.-K. (eds.) Handbook of Water and Energy Management in Food Processing, pp. 929-995. Woodhead Publishing, Cambridge (2008)

116. Bones, A., Sire, Y.: Impacts of winemaking methods on wastewaters and their treatment. S. Afr. J. Enol. Vitic. 1, 38-44 (2010)

117. Elliott, D.C., et al.: Biorefinery concept development based on wheat flour milling. Fuel Chem. Div. Prep. 47, 361-362 (2002)

118. EAUC Environmental Association for Universities and Colleges (EAUC): The Classification of Waste (2016). http://www.eauc. org.uk/home. Accessed 19 May 2016

119. Cohn, T., Bones, A., Sire, Y., Perrin, R.: Treatment and valorisation of winery wastewater by a new bio-physical process. Water Sci. Technol. 1, 99-106(2005) 